\title{
THE SUCCESS RATE OF ARTIFICIAL INSEMINATION USING SEXING LIQUID SEMEN WITH DIFFERENT METHODS IN BALI HEIFER
}

\author{
Monica Vera*, Postgraduate Student \\ Faculty of Animal Husbandry, University of Brawijaya, Indonesia \\ Dewi Putu Bulan Sasmita, Hartono Slamet, Pujianto Jack \\ BPTU and HPT Denpasar, Indonesia
}

Isnaini Nurul, Yekti Aulia Puspita Anugra, Susilawati Trinil, Lecturers

Faculty of Animal Husbandry, University of Brawijaya, Indonesia

*E-mail: vevemon2@gmail.com

\begin{abstract}
Artificial Insemination (AI) in this study uses the results of sexing liquid semen, which aims to get the calf following the objective of the breeding institution that is producing Bali cows. The study was conducted at Balai Pembibitan Ternak Unggul and Hijauan Pakan Ternak located in Pangyangan, Pulukan Sub district, Jembrana Regency, Bali. The study was conducted on July 7, 2019 until November 7, 2019. The research material was 45 Bali heifers. Bali heifer was synchronized using Enzaprost@, after showing signs of estrus, double doses artificial insemination at 2 hours after estrus and 8 hours after estrus. The Bali heifer was inseminated with non-sexing and sexing liquid semen using andromed diluent, P0 = non-sexing liquid semen, P1 = liquid semen by the Percoll Density Gradient Centrifugation (PDGC) method in the lower layer and P2 = liquid semen by the Egg White Gradient Sedimentation (EWS) method in the upper layer. Pregnancy evaluation is calculated based on Non-Return Rate (NRR) and Conception Rate (CR). The results showed Non-Return Rate (NRR) P0, P1 and $\mathrm{P} 2=86.67 \%, 60 \%$ and $53.33 \%$. While the Conception Rate $(\mathrm{CR})$ at P0, P1 and P2 is $53.33 \%, 13.33 \%$ and $26.67 \%$.
\end{abstract}

\section{KEY WORDS}

Artificial insemination, liquid semen, sexing, NRR.

Artificial Insemination (Al) is a reproductive technology that can improve genetic quality in livestock and can produce large numbers of a good quality calf by using a lot bulls (Susilawati, 2011). One of the materials that need to be prepared in artificial insemination is used semen. In this research using spermatozoa sexing is one of the results of reproductive technology which is considered as a promising alternative in the effort of reproductive efficiency to produce a calf of the desired sex. The purpose of Artificial Insemination using sexing semen is to get calf as expected and save money in the livestock business. Sexing is the separation of spermatozoa $X$ and $Y$. To separate semen $X$ and $Y$ requires Percoll Density Gradient Centrifugation (PDGC) method, Susilawati (2014) states that sexing using percoll density gradient centrifugation method can separate with a precision of more than $80 \%$ based on identification measuring the head of spermatozoa and Egg White Gradient Sedimentation (EWG), Sianturi et al (2004), states Sexing using albumin or egg white has the principle of making a medium that has different concentrations, so that high spermatozoa motility $(Y)$ would be able to pierce a deeper concentration of medium, while spermatozoa $X$ could stay on a medium that could be a low concentration, Afiati (2004) states that the percentage of spermatozoa resulting from albumin gradient sexing predicted $\mathrm{X}$ chromosome by $80.88 \%$ and $Y$ by $58.82 \%$ with motility after the sexing process reached $75.00 \%$.

The results of Al studies using liquid semen NRR numbers $81.48 \%$ and CR $59.26 \%$ (Saifudin et al, 2018). This research aims to evaluate the success of Artificial Insemination (IB) using non-sexing and sexing liquid semen with Percoll Density Gradient Centrifugation 
(PDGC) and Egg White Gradient Sedimentation (EWG) in Bali heifer based on NRR and CR which are parameters of successful artificial insemination.

\section{MATERIALS AND METHODS OF RESEARCH}

The research was conducted at the BPTU and HPT Denpasar Laboratory (Balai Pembibitan Ternak Unggul and Hijauan Pakan Ternak) located in Pangyangan, Kecamatan Pulukan, Kabupaten Jembrana, Bali. The study was conducted on July 8, 2019 until November 7, 2019.

The material used in this study is 45 Bali heifers. The Bali heifers is selected according to the criteria of having a healthy reproductive condition, Body Condition Score (BCS): 2.5 - 3 (score: 1-5), age 1.5-2 years and good quality of estrus. Sexing liquid semen made in the Laboratory of the Balai Pembibitan Ternak Unggul and Hijauan Pakan Ternak (BPTU and HPT) Denpasar using the Percoll Density Gradient Centrifugation (PDGC) and Egg White Gradient Sedimentation (EWG) methods.

The research method used was an experimental method with a field experiment. The treatments used in this study were Percoll Density Gradient Centrifugation and Egg White Gradient Sedimentation conducted in the laboratory of the Superior Livestock Balai Pembibitan Ternak Unggul and Hijauan Pakan Ternak, Denpasar. The aim is to evaluate the success of $\mathrm{Al}$ using semen from sexing $X$ in Bali heifer. There are three treatments:

- (P0): liquid semen with andromed diluent;

- (P1): sexing liquid semen using Percoll Density Gradient Centrifugation (PDGC) method;

- (P2): sexing liquid semen using Egg White Gradient Sedimentation (EWG) method.

The liquid semen used in this research was andromed diluents. Andromed diluents have a composition in the form of aquabidest, fructose, glycerol, citric acid, buffer, phosifolipid, spectynomicine, lincomicine $15 \mathrm{mg}$, tylocin $15 \mathrm{mg}$, gentamycine $25 \mathrm{mg}$ which is made by adding aquabidest 1: 4 ratio then homogenized (Susilawati, 2011). The method of making andromed diluent according to Susilawati (2011), andromed was put into a measuring cup, added a 1: 4 aquabidest ratio, then homogenized, set in a water bath with a temperature of $38^{\circ} \mathrm{C}$, ready to be used for thinners.

Making liquid semen using the Egg White Gradient Sedimentation (EWG) method is to make gradients with percentages of $10 \%, 30 \%$ and $50 \%$ which will be arranged in tubes in a sequence from the highest density to the lowest of $1,5 \mathrm{ml}$ each. Then put $2 \mathrm{ml}$ of semen into gradient tube and put into the waterbath and do the refrigerator for 20 minutes, do the separation of spermatozoa $X$ in the top layer which is put into the test tube as much as $2 \mathrm{ml}$ with $3 \mathrm{ml}$ of diluent and centrifuged at $1500 \mathrm{rpm}$ for 5 minutes. The supernatant was removed and $1 \mathrm{ml}$ is left and the semen was evaluated (Susilawati, 2014).

Synchronization in Bali heifer using PGF2 Alfa with the brand Enzaprost with $5 \mathrm{mg}$ dinoprost composition, $1 \mathrm{ml}$ excipient. Synchronization was carried out on 45 Bali heifers. Synchronizing with the two-injection method that is on the first day is injected PGF2 Alfa as much as $5 \mathrm{mg}$, if the Bali heifer were found to estrus, then Artificial Insemination will be done that same day. Inspection of estrus has a sign of riding each other or want to ride another cow, issued mucus. If after injection, the first Alfa PGF2 does not show any signs of estrus, then the second PGF2 Alfa injection is continued on the 11th day. And on the 13th day will be a re-examination of estrus and livestock in Artificial Insemination.

The Al was carried out by observing the estrus first and the Bali heifer which was initially in the paddock and was considered to be lust were directly herded or put into a staple cage and observed the vulva colour, vulva temperature, cervical mucus conditions (Roelofs et al, 2005). Experienced inseminator officers will artificially inseminate Bali heifer found in estrus.

Observed variables include:

a. Non Return Rate (NRR). NRR value is obtained by observing estrus again on days 17-21 after the Al. The Bali cow that does not have signs of estrus are assumed to be 
pregnant if cattle are found in estrus, it is assumed that the cow are not pregnant, (Jainudeen and Hafez, 2008). The NRR formula is:

$\mathrm{NRR}=$ the number of non estrus cows returned $\times 100 \%$ the total number of artificial inseminated cows

b. Conception Rate (CR). CR values were found after counting pregnant cow using rectal palpation at the first $\mathrm{Al}$ (Susilawati, 2011) and (Caraviello et al, 2006). The formulas used are:

$\mathrm{CR}=\underline{\text { the number of pregnant females the first Al result diagnosed rectal }} \times 100 \%$ the total number of females wese inseminated

Data obtained from this research were calculated descriptive using Microsoft Excel and analyzed using the chi-square test.

\section{RESULTS AND DISCUSSION}

Pregnancy Evaluation Based on Non Return Rate (NRR). Non Return Rate (NRR) is cattle does not shoe back estrus after the Al. NRR observations were made after 60 days after Al. Susilawati (2013) and (Costa et al, 2016) states that NRR is the number of cow that do not show estrus between 20-60 days or 60-90 days. Meanwhile, according to Sianturi et al. (2016), NRR is a tool for pregnancy detection which is a percentage of the number of cowthat are not show estrus after artificial insemination with sexed sperm in 21-day Al observations. NRR also has a method based on livestock that does not show estrus again is considered pregnant (Susilawati, 2011). The results of Artificial Insemination (AI) using liquid semen including NRR can be seen in Table 1.

Table 1 - Result of Non-Return Rate (NRR) Counts

\begin{tabular}{cccc}
\hline \multirow{2}{*}{ Treatment } & Bali Heifer & \multicolumn{2}{c}{ Non Return Rate } \\
\cline { 3 - 4 } & 15 & 13 & $\%$ \\
\hline Non Sexing & 15 & 9 & 86,67 \\
\hline PDGC & 15 & 8 & 60 \\
\hline EWG & & 53,33 \\
\hline
\end{tabular}

Note: PDGC - Percoll Density Gradient Centrifugation; EWC - Egg White Gradient Sedimentation.

From Table 1. it can be seen that the percentage of NRR with three treatments has a percentage above $50 \%$. Kusumawati et al (2019) state that the NRR value is still said to be useful in the category above $50 \%$. The result of research Susilawati (2015) result of semen non sexing obtained a lower percentage is $74,07 \%$, in this research obtained is $86,87 \%$. While the results of research Susilawati et al. (2019) results of Al using frozen semen sexing using centrifugation Gradient Percoll density method NRR1 value is $76.91 \%$. Rosita et al. (2014) research results from $\mathrm{Al}$ using frozen semen sexing using egg white gradient sedimentation method NRR1 value was $74 \%$, higher than this research. Of the three treatments P0 (non-sexing) had a high NRR compared to the sexing treatment of Percoll Gradient Density and Egg White Gradient Sedimentation, namely P1: 60\% and P2: 53.33\%. Rosita et al. (2014) stated that the NRR value in the treatment of cow insemination by nonsexing semen was higher than the NRR of the cow that was insemination by sexing results. However, it is still said to be a good category. Low NRR percentage can be caused by several factors, including feeding, Jaenudin and Hafez (2008) states that the conception rate can be influenced by feed quality. Susilawati (2011) states that the protein in the reduced ration given to cow breeders causes weak estrus, repeat mating, premature embryonic death and abortion. Early embryonic death is caused by ectoparasites and endoparasites which cause stress in cattle and will interfere the reproduction condition.

Pregnancy Evaluation Based on Conception Rate (CR). Conception Rate (CR) aims to identify pregnant cow by rectal palpation after the first artificial insemination (AI). Saifudin et 
al. (2018) stated the Conception rate is how many cows are pregnant at the first Al. CR values are said to be ideal if they reach $60 \%$ (Ihsan and Wahjuningsih). The CR calculation results can be seen in Table 2 as follows:

Table 2 - Results of Conception Rate (CR) Counts

\begin{tabular}{cccc}
\hline Treatment & \multirow{2}{*}{ Bali Heifer } & \multicolumn{2}{c}{ Conception Rate } \\
\cline { 3 - 4 } Non Sexing & 15 & Bali Heifer & $\%$ \\
\hline PDGC & 15 & 8 & 53,33 \\
\hline EWC & 15 & 2 & 13,33 \\
\hline
\end{tabular}

Note: PDGC - Percoll Density Gradient Centrifugation; EWC - Egg White Gradient Sedimentation.

From Table 2. it can be seen that the CR value of each treatment shows P0 (nonsexing / control): $53.33 \%$ which is still categorized below the ideal treatment P1 (SGDP): $13.33 \%$ and P2 (SGPT): $26.67 \%$. The lowest CR is P1 which is $13.33 \%$ with sexing treatment using the Percoll Density Gradient Centrifugation method. However, the CR rate on Al using non-sexing liquid semen is higher than the CR number on Al using sexing liquid semen. Yekti et al (2018) in research that the CR value on Al using sexing liquid semen is lower than non-sexing liquid semen namely 55, $10 \%$ and $65.31 \%$. Compared to the research of Saifudin et al (2018) it had a liquid CR rate of $59.26 \%$ higher than this study which had a non-sexing liquid CR rate as a control that was 53.33\% and Kusumawati (2019) it has a low percentage result is $46,67 \%$. Costa et al (2016) result of conception rate in liquid semen sexing higher is $86,6 \%$ compared to this research. Susilawati et al. (2019) results of Conception Rate of Ongole cattle in Al using frozen semen sexing results were $83.84 \%$.

Several factors can cause the low CR rate in this research, namely the experience of inseminators in Al can because in BPTU and HPT Denpasar themselves are still starting AI in 2018, semen deposition also affects low CR numbers. Susilawati (2004) said that the CR value was influenced by the deposition of semen during Artificial Insemination ( $\mathrm{Al}$ ), in this study the deposition of semen during AI was 2, 3 and 4 whereas in Fernanda's (2014) and Seidel and Schenk (2008) study stated that the CR number at position 4 was lower namely $70 \%$ compared to position $4+, 80 \%$.

\section{CONCLUSION}

Artificial Insemination using non-sexing and sexing liquid semen against NRR figures showed above $50 \%$ for each treatment and non-sexing and sexing CR numbers below the ideal number for each treatment was P0: 53.33\%. P1: 13.33\% and P2: $26.67 \%$.

\section{ACKNOWLEDGMENTS}

BPTU and HPT Denpasar have provided research facilities.

\section{REFERENCES}

1. Afiati, F. 2004. Proporsi and Karakteristik Spermatozoa X and Y Hasil Separasi Kolom Albumin. Media Peternakan, 27(1), 18-19.

2. Caraviello, D. Z., K. A. Weigel, M. Craven, D. Glanola, K. V. Nordlund, P. M. Fricke and M. C. Wiltbank. 2006. Analysis of Reproductive Performance of Lactating Cows on Large Dairy Farms Using Machine Learning Algorithms. J. Dairy Sci. 89:4703-4722.

3. Costa, N. D.,T. Susilawati, N. Isnaiani and M. N. Ihsan. 2016. The Difference of Artificial Insemination Successful Rate of Onggole Filial Cattle Using Cold Semen with Different Storage Time with Tris Aminomethane Egg Yolk Dilution Agent. Journal Of Pharmacy. 6(6): 14-16. 
4. Fernanda, M. T., T. Susilawati, and N. Isnaini. 2014. Keberhasilan IB menggunakan Semen Beku Hasil Sexing dengan metode Sentrifugasi Gradien Densitas Percoll (SGDP) pada Sapi Peranakan Ongole (PO). Jurnal Ilmu-IImu Peternakan, 24(3), 4-7.

5. Ihsan, M. N. and S. Wahjuningsih. 2011. Penampilan Reproduksi Sapi Potong di Kabupaten Bojonegoro. J. Ilmu-IImu Peternakan 24 (3):1 - 8.

6. Jainudeen, M. R. and E. S. E., Hafez. 2008. Cattle and buffalo. Dalam Reproduction in farm animals. 7 th edition edited by Hafez E. S. E. Lippincott Williams \& Wilkins. Maryland. J. Ilmu-IImu Peternakan 24 (3):1 - 8.

7. Kusumawati, E. D., T. Susilawati, N. Isnaini, S. Rahayu, A. P. A. Yekti, K. Kuswati, A. Ridhowi and S. Rahadi. 2019. Artificial Insemination using liquid sperm Filial Ongole Bull after sexed with different methods. Journal of Physics: Conference Series. 1375 (2019) 012019: 2.

8. Roelofs, J. B., F. J. C. M. van Eerdenburgb, N. M. Soedea and B. Kemp. 2005. Various behavioral signs of estrous and their relationship with time of ovulation in dairy cattle. Theriogenology. 63 (2005) 1366-1377.

9. Rosita, E. A., T. Susilawati and S. Wahyuningsih. 2014. Keberhasilan IB Menggunakan Semen Beku Hasil Sexing Dengan Metode Sedimentasi Putih Telur Pada Sapi PO Cross. Jurnal IImu-IImu Peternakan 24 (1): 72 - 76.

10. Seidel, G.e and J. L. Schenk. 2008. Pregnancy Rates In Cattle With Cryopreserved Sexed Sperm: Effects Of Sperm Numbers Per Inseminate And Site Of Sperm Deposition. Animal Reproduction Science 105 (2008): 129-138.

11. Saifudin, M., N. Isnaini, A. P. A. Yekti, T. Susilawati. 2018. Tingkat Keberhasilan Inseminasi Buatan Menggunakan Semen Cair Menggunakan Media Pengencer Tris Aminomethan Kuning Telur Pada Sapi Persilangan Ongole. Jurnal Ternak Tropika: 19(1): 62-64.

12. Sianturi, R. G., P. Situmorang, E. Triwulanningsih, and D. A. Kusumaningrum. 2004. Pengaruh Isobutil Metilxantina (IMX) and Waktu Pemisahan Terhadap Kualitas and Efektifitas Pemisahan Spermatozoa Dengan Metode Kolom Albumin Putih Telur. Buletin Peternakan, 41: (1).

13. Sianturi, T. Saili and L. O. Nafiu. 2016. Karakteristik Spermatozoa Sapi Bali Setelah Sexing Menggunakan Metode Kolom Albumin Dengan Lama Waktu Sexing Yang Berbeda. Jitro. 3(1):74.

14. Susilawati T. 2004. Keberhasilan IB Menggunakan Semen Sexing Setelah Dibekukan. J. Ilmu-Ilmu Peternakan 24 (3):1 - 8.

15. Susilawati, T. 2011. Tingkat Keberhasilan Inseminasi Buatan Dengan Kualitas and Deposisi Semen Yang Berbeda Pada Sapi Peranakan Ongole. J. IImu-IImu Peternakan $24(3): 1-8$.

16. Susilawati, T. 2011. Spermatologi. Universitas Brawijaya. Press: Malang.

17. Susilawati, T. 2013. Pedoman Inseminasi Buatan pada Ternak. Malang: UB Press.

18. Susilawati, T. 2014. Sexing Spermatozoa (Hasil Penelitian Laboratorium and Aplikasi pada Sapi and Kambing). Universitas Brawijaya. Press: Malang.

19. Susilawati, T., L. Wahyudi, N. Isnaini and A. P. A. Yekti. 2015. Reproductive Performances of Ongole Crossbred Cattle Using Artifcial Insemination Sexed Semen with Diferrent Methods. Te 6th International Seminar on Tropical Animal Production: Yogyakarta.

20. Susilawati,T, Kuswati and A.P.A.Yekti (2019) The Success Rate of Artificial Insemination (AI) Using Sexing and Non Sexing Frozen Semen in Ongole Crossbred Cows. Asian Jr.of.Microbiol. Biotech. Env. Sc. 21(2): 537-540.

21. Susilawati, T., A. Mahfud, N. Isnaini, A. P. A. Yekti, A. N. Huda, A. T. Satria and Kuswati. 2019. The comparison of artificial insemination success between unsexed and sexed sperm in Ongole Crossbred cattle. IOP Conf. Series: Earth and Environmental Science 387 (2019) 012010.

22. Yekti, A. P. A., T. U. Kurniaesa, N. Isnaini, Kuswati, and T. Susilawati. 2018. Conception Rate Hasil Inseminasi Buatan menggunakan Semen Sexing Beku pada Sapi Persilangan Ongole. Jurnal Ilmu-IImu Peternakan, 28(3): 241-246. 